\author{
KS. MAREK STĘPIEŃ \\ Wydział Prawa Kanonicznego \\ Uniwersytet Kardynała Stefana Wyszyńskiego w Warszawie \\ ORCID: 0000-0002-5049-1480
}

\title{
RELACJE KONFERENCJI EPISKOPATU POLSKI Z WŁADZAMI POLSKIEJ RZECZYPOSPOLITEJ LUDOWEJ W LATACH 1980-1981
}

Treść: Wstęp. - 1. Koncepcje ułożenia stosunków między Kościołem w Polsce a władzami PRL prezentowane przez strony na przełomie lat siedemdziesiątych i osiemdziesiątych - 2. Działalność Komisji Wspólnej przedstawicieli rządu i Episkopatu - 3. Rozmowy i wymiana korespondencji prowadzone przez przedstawicieli Konferencji Episkopatu Polski z władzami PRL - 4. Podsumowanie i wnioski - Zakończenie.

\section{Wstęp}

Na początku lat siedemdziesiątych XX w. władze komunistyczne w Polsce, po zmianie kierownictwa PZPR, starały się uspokoić nastroje społeczne i wyszły z propozycją normalizacji stosunków z Kościołem w Polsce. Mimo, że biskupi polscy odnieśli się pozytywnie do tej deklaracji, to jednak w latach siedemdziesiątych ubiegłego wieku nie nastąpiła normalizacja wzajemnych stosunków ${ }^{1}$ Udało

\footnotetext{
${ }^{1}$ Więcej na ten temat zobacz: M. StęPIEŃ, Relacje Konferencji Episkopatu Polski z władzami Polskiej Rzeczypospolitej Ludowej w pierwszej połowie lat siedemdziesiątych XX wieku, Warszawskie Studia Pastoralne XIII 41 (2018) nr 4, s. 209-232; M. StęPIEŃ, Relacje Konferencji Episkopatu Polski z władzami Polskiej Rzeczypospolitej Ludowej w drugiej połowie lat siedemdziesiątych XX wieku, Prawo Kanoniczne 61 (2018) nr 3, s. 73-105.
} 
się jedynie załatwić trzy sprawy: częściowo przywrócić własność Kościołowi na ziemiach zachodnich i północnych, umorzyć niesprawiedliwie wymierzane czynsze na tych terenach i uchylić obowiązek prowadzenia ksiąg inwentarzowych. W zasadniczych sprawach komuniści nie zamierzali ustępować i zawierać całościowego porozumienia z Kościołem w Polsce, a wręcz uznali, że będzie lepiej podjąć dwustronne rokowania ze Stolicą Apostolską, z wyłączeniem z nich Episkopatu Polski. W wyniku tych rozmów w lipcu 1974 r. strony podpisały Protokół, na mocy którego Stolica Apostolska i Rząd PRL zobowiązali się ustanowić stałe kontakty robocze realizowane przez zespoły przedstawicieli każdej ze stron. Zespół Rządu PRL rozpoczął wówczas pracę w Rzymie przy ambasadzie Polski, natomiast Zespół strony watykańskiej miał w przyszłości przybyć do Warszawy, kiedy Stolica Apostolska uznałaby to za stosowne ${ }^{2}$. Biskupi na Zebraniu Plenarnym Konferencji Episkopatu Polski w Warszawie w dniach 15 i 16 stycznia 1975 r. podkreślili w komunikacie, że władze PRL nie podjęły szeregu ważnych spraw z zakresu normalizacji wzajemnych stosunków ${ }^{3}$.

Zdaniem kard. Stefana Wyszyńskiego, przewodniczącego Konferencji Episkopatu i prymasa Polski, złe relacje między państwem a Kościołem w latach siedemdziesiątych ubiegłego wieku wynikały, przede wszystkim, ze stosowania przez władzę ideologii materialistycznej, gdzie uznawano każdą religię, w tym chrześcijaństwo, za

\footnotetext{
${ }^{2}$ Kopia Protokołu podpisanego przez abpa Agostino Casarolego, sekretarza Rady do Spraw Publicznych Kościoła i Józefa Czyrka, wiceministra spraw zagranicznych PRL. Rzym, 06-07-1974 (polska i włoska wersja językowa). Archiwum Konferencji Episkopatu Polski - adres: Skwer Ks. Kard. S. Wyszyńskiego 6, 01-015 Warszawa (skrót: AKEP), sygn. Archiwum 1969-1979 (skrót: II) 0032. Na temat roli Konferencji Episkopatu Polski w rokowaniach Stolicy Apostolskiej z władzami PRL zobacz: M. STĘPIEŃ, Rola Konferencji Episkopatu Polski w rokowaniach Stolicy Apostolskiej z władzami Polskiej Rzeczypospolitej Ludowej w pierwszej połowie lat siedemdziesiątych XX wieku, Warszawskie Studia Pastoralne XIII 41 (2018) nr 4, s. 233-252.

${ }^{3}$ Rys historyczny Komisji Mieszanej - Wspólnej na tle stosunków Kościół - Państwo w Polsce 1949-1990. Warszawa (bez daty), sygn. Archiwum 1980-1989 (skrót: III) 03059 , s. 1-2.
} 
czynnik społecznie negatywny. Prymas Polski postulował między innymi uznanie przez państwo Kościoła katolickiego jako osoby prawnej prawa publicznego i organizacji społecznej oraz zaaprobowanie zasady, że Kościół kieruje się własnymi normami prawnymi, a państwo powinno zapewnić swobodę wykonywania w Kościele władzy duchowej i jurysdykcji.

Niniejszy artykuł jest kontynuacją cyklu publikacji autora i ma na celu ukazanie relacji Konferencji Episkopatu Polski z władzami Polskiej Rzeczypospolitej Ludowej w latach 1980-1981, czyli w czasie następujących zmian społeczno-politycznych, czego konsekwencją było utworzenie Niezależnego Samorządnego Związku Zawodowego „Solidarność”.

\section{Koncepcje ułożenia stosunków między Kościołem w Polsce a władzami PRL prezentowane przez strony na przełomie lat siedemdziesiątych i osiemdziesiątych}

Całościową wizję relacji Kościoła w Polsce z władzami komunistycznymi przygotował kard. Stefan Wyszyński, przewodniczący Konferencji Episkopatu Polski, jeszcze w drugiej połowie lat siedemdziesiątych ubiegłego wieku. W obszernym opracowaniu tematów, przed rozmową z Edwardem Gierkiem, pierwszym sekretarzem KC PZPR, kardynał uwzględnił następujące kwestie: problemy równości obywatelskiej (przeciwstawienie się wszelkiej dyskryminacji); zagadnienia dotyczące rodziny i moralności społecznej; współdziałanie Kościoła i państwa w życiu społeczeństwa i narodu oraz rozwiązanie problemów społecznych, w celu zachowania spokoju w Polsce; rozmowy prowadzone przez Stolicę Apostolską z Rządem PRL; przyjazdu do Polski Jana Pawła II w 1979 r. ${ }^{4}$ Prymas Polski uznał za niezbędne we wzajemnych relacjach stosowanie zasady współdziałania, w oparciu o prawne uznanie przez państwo miejsca Kościoła w Polsce i suwerenności kraju oraz poszanowanie przez państwo wartości kultury narodowej. Postulował też wspólne działania na rzecz jedności mo-

\footnotetext{
${ }^{4}$ Kard. S. Wyszyński. Tematy do rozmowy w dniu 24.I.1979. AKEP, sygn. II 031700, s. 1-2.
} 
ralno-politycznej i kulturalnej narodu, na wszystkich płaszczyznach życia w kraju ${ }^{5}$.

Władze komunistyczne w Polsce, na początku lat siedemdziesiątych, zdecydowały się nawiązać rozmowy ze Stolicą Apostolską, których celem było uwiarygodnienie się na arenie międzynarodowej oraz wyłączenie z negocjacji biskupów polskich i wykluczenie wywierania przez nich jakiegokolwiek wpływu na ich prowadzenie. Sformułowano postulaty, które miały być przekazane w czasie prowadzonych rokowań. Najważniejsze z nich to: usunięcie przedstawiciela rządu londyńskiego przy Watykanie, uznanie, że konkordat z 1925 r. nie obowiązuje z winy Watykanu, aprobata ze strony Stolicy Apostolskiej wpływu władz PRL na obsadę stanowisk kościelnych i rozbudowę organizacyjną Kościoła, uznanie przez Stolicę Apostolską ustroju PRL jako rzeczywistości trwałej oraz powstrzymanie hierarchów Kościoła w Polsce przed wypowiadaniem się na temat życia publicznego i politycznego w Polsce ${ }^{6}$.

Plan władz komunistycznych PRL nie powiódł się, gdyż dyplomaci Watykanu podchodzili z dużą ostrożnością do rokowań, mając uzasadnione obawy, że ewentualne porozumienie będzie wykorzystane instrumentalnie przez drugą stronę. Jednocześnie przedstawiciele Stolicy Apostolskiej jasno stwierdzili, że ta w nawiązywaniu kontaktów dyplomatycznych z państwami zawsze ściśle współpracuje z zainteresowanymi konferencjami biskupów, w tym także z Konferencją Episkopatu Polski. Takie stanowisko Stolicy Apostolskiej przedstawił na forum międzynarodowym abp Agostino Casaroli, sekretarz Rady do Spraw Publicznych Kościoła, stwierdzając w czasie swego pobytu w Helsinkach, że Stolica Apostolska w nawiązywaniu kontaktów z państwami będzie ściśle współpracowała z zainteresowanymi konferencjami biskupów ${ }^{7}$. Rokowania prowadzone przez przedstawicieli Stolicy Apostolskiej i Rządu PRL w latach siedem-

\footnotetext{
${ }^{5}$ Tamże, s. 2-5.

${ }^{6}$ Rządowy „Pakiet postulatów”. Warszawa, 26-04-1971. AKEP, sygn. II 0032.

${ }^{7}$ List. Abp A. Casaroli do kard. S. Wyszyńskiego. Watykan, 24-07-1973. AKEP, sygn. II 0032.
} 
dziesiątych ubiegłego wieku nie przyniosły znaczących rezultatów, nie zawarto całościowego porozumienia oraz nie udało się władzom państwowym doprowadzić do izolowania biskupów polskich.

W dokumencie z lutego 1980 r. sporządzonym przez bpa Bronisława Dąbrowskiego, sekretarza Konferencji Episkopatu Polski, dla Stanisława Kani, sekretarza KC PZPR, duchowny podkreślił, że Kościół w Polsce nie żąda przywilejów, ale elementarnego przywrócenia praw instytucjom kościelnym, które zostały ich bezprawnie pozbawione „w okresie błędów i wypaczeń”. Dlatego Kościół w Polsce domaga się: wolności sumienia i wyznania, bez jakiejkolwiek dyskryminacji, w tym obywateli wierzących; wolności duszpastersko-kultowej Kościoła, szczególnie odstąpienie od zwalczania przez państwo duszpasterstwa młodzieżowego i pozbawiania dzieci w internatach oraz domach dziecka prawa do katechizacji i uczestnictwa w niedzielnej Mszy św.; zaprzestania dyskryminacji alumnów, którzy powoływani są do odbycia zasadniczej służby wojskowej; zaprzestania dyskryminacji w kwestiach różnego rodzaju publikacji - przydziału papieru, wysokości nakładów i cenzurowania tekstów. Jak zaznaczył bp Dąbrowski, normalizacja stosunków między stronami może nastąpić tylko wtedy, gdy władze wycofają się z politycznego popierania ateizacji, przyznają Kościołowi status prawno-publiczny8.

We wrześniu 1980 r. nastąpiły zmiany osobowe na najwyższych szczeblach PZPR i Rządu PRL, co było spowodowane niepokojami społecznymi. Stanisław Kania zastąpił Edwarda Gierka na stanowisku pierwszego sekretarza KC PZPR. Nowy prezes Rady Ministrów Józef Pińkowski, zapewnił na posiedzeniu plenarnym Sejmu PRL, że rząd będzie dążył do normalizacji stosunków państwo - Kościół i zgodzi się na wznowienie prac Komisji Wspólnej przedstawicieli Episkopatu i Rządu PRL9.

\footnotetext{
${ }^{8}$ Bp B. Dąbrowski. Kopia Pro memoria dla Pana Stanisława Kani, Sekretarza KC PZPR. Warszawa, 07-02-1980. AKEP, sygn. III 0200.

${ }^{9}$ Rys historyczny Komisji Mieszanej - Wspólnej na tle stosunków Kościół - Państwo w Polsce 1949-1990. Warszawa (bez daty). AKEP), sygn. III 03059, s. 157.
} 
Już 10 września 1980 r. w Sekretariacie Konferencji Episkopatu Polski sporządzono postulaty, od których spełnienia uzależniono pełną normalizację stosunków między Kościołem a państwem w PRL. Zostały one podzielone na osiem grup, w tym między innymi te dotyczące: osobowości publiczno-prawnej Kościoła i instytucji kościelnych, praworządności w stosunku do obywateli, w tym obywateli wierzących oraz troski o rozwój biologiczny i moralny narodu; wolności obywatelskich i religijnych, sumienia i wyznania, wolności sprawowania kultu religijnego, wolności stowarzyszeń, słowa i prasy, prawa do pracy, nauki i ubezpieczeń społecznych; wolności obsadzania stanowisk kościelnych, erygowania parafii, katechizacji, prowadzenia duszpasterstwa w wojsku, szpitalach i zakładach karnych, zaprzestania poboru kleryków do odbywania zasadniczej służby wojskowej; nadania statusu prawnego zakonom i zgromadzeniom zakonnym, umożliwienie działalności charytatywnej, zwrot nieruchomości, egzekwowanie prawa członków zgromadzeń do nauki, pracy i ubezpieczeń społecznych ${ }^{10}$.

\section{Działalność Komisji Wspólnej przedstawicieli rządu i Episkopatu}

Władze państwowe w latach siedemdziesiątych ubiegłego wieku nie zgadzały się na reaktywację Komisji Wspólnej przedstawicieli Rządu PRL i Episkopatu. Ostatnie posiedzenie tego gremium odbyło się w dniu 20 stycznia 1967 r. ${ }^{11}$ Biskupi obradujący na 174. Zebraniu Plenarnym Konferencji Episkopatu Polski, na Górze św. Anny w dniu 28 czerwca 1980 r., delegowali do „Komisji Mieszanej ad hoc” kard. Franciszka Macharskiego, bpa Lecha Kaczmarka i bpa Bronisława Dąbrowskiego, w celu omówienia niektórych problemów dotyczących normalizacji stosunków Kościół - państwo, o czym sekretarz Konfe-

\footnotetext{
${ }^{10}$ Sekretariat Konferencji Episkopatu Polski. Postulaty Kościoła Rzym.-Kat. Niezbędne dla pełnej normalizacji stosunków między Państwem a Kościołem w PRL. Warszawa, 10-09-1980. AKEP, sygn. III 0200.

${ }^{11}$ Rys historyczny Komisji Mieszanej - Wspólnej na tle stosunków Kościół - Państwo w Polsce 1949-1990. Warszawa (bez daty). AKEP, sygn. III 03059, s. 111.
} 
rencji Episkopatu Polski poinformował min. Jerzego Kuberskiego, kierownika Urzędu do Spraw Wyznań, pismem z dnia 1 sierpnia 1980 r. ${ }^{12}$

Nowy premier PRL Józef Pińkowski zadeklarował w sejmie w dniu 5 września 1980 r. gotowość wznowienia działalności Komisji Wspólnej przedstawicieli rządu i Episkopatu, co było odpowiedzią na zapytanie posła Janusza Zabłockiego o stan stosunków Kościół - państwo. Pierwsze posiedzenie tego gremium odbyto już 23 września 1980 r. w Urzędzie Rady Ministrów w Warszawie. W zebraniu wzięli udział: ze strony rządu wicepremier Kazimierz Barcikowski, min. Jerzy Kuberski, kierownik Urzędu do Spraw Wyznań i jego zastępca Aleksander Merker oraz ze strony Episkopatu Polski kard. Franciszek Macharski, bp Lech Kaczmarek i bp Bronisław Dąbrowski ${ }^{13}$.

W czasie posiedzenia Komisji Wspólnej, po ponad dziesięcioletniej przerwie, wicepremier Barcikowski wyraził zobowiązanie, że strona rządowa będzie dokładać starań, aby rozmowy z przedstawicielami Episkopatu były konstruktywne i w efekcie doprowadziły do rozwiązania jak największej liczby spraw. Jednocześnie wicepremier podkreślił, że rozmowy na forum Komisji Wspólnej będą miały charakter wiążący. Poinformował też zebranych, że strona rządowa desygnuje do składu Komisji Wspólnej posła Witolda Lipskiego, przedstawiciela Stronnictwa Ludowego, aby, jak się wyraził, członkowie tego Stronnictwa orientowali się w aktualnych relacjach Kościół - państwo, co zdaniem rządzących będzie zapewnione przez obecność „czynnika społecznego" w tym gremium ${ }^{14}$.

W Pro memoria sporządzonym w dniu 8 października 1980 r. bp Bronisław Dąbrowski poinformował stronę rządową, że kard. Stefan Wyszyński, przewodniczący Konferencji Episkopatu i prymas

\footnotetext{
${ }^{12}$ Kopia pisma. Bp B. Dąbrowski do J. Kuberskiego. Warszawa, 01-08-1980. AKEP, sygn. III 0305.

${ }^{13}$ Sprawozdanie z posiedzenia Komisji Wspólnej Rządu i Episkopatu. Warszawa, 24 września 1980 r. g. 17 do 20.00 (jest błędnie podany dzień - powinno być 23 września). Warszawa, 24-09-1980. AKEP, sygn. III 03050. Zob. Rys historyczny Komisji Mieszanej - Wspólnej na tle stosunków Kościół - Państwo w Polsce 19491990. Warszawa (bez daty). AKEP, sygn. III 03059, s. 157.

${ }^{14}$ Tamże.
} 
Polski, przyjmuje do wiadomości skład przedstawicieli rządu w Komisji Wspólnej, gdyż kieruje się zasadą, że każda ze stron władna jest desygnować i odwoływać swoich przedstawicieli ${ }^{15}$. Dokument ten został wręczony min. Jerzemu Kuberskiemu, kierownikowi Urzędu do Spraw Wyznań, przez sekretarza Konferencji Episkopatu Polski, w czasie rozmów przeprowadzonych następnego dnia. Wówczas minister poinformował, że Kazimierz Barcikowski został odwołany z funkcji wicepremiera, gdyż został sekretarzem KC PZPR i z ramienia partii będzie miał w swoich kompetencjach sprawy stosunków Kościół - państwo i jednocześnie zachowa stanowisko przewodniczącego Komisji Wspólnej.

Minister Kuberski wskazał trzy grupy tematów, którymi, zdaniem władz, powinna zająć się Komisja Wspólna: 1) wzajemne współdziałanie Kościoła i państwa, z uwzględnieniem publiczno-prawnej osobowości Kościoła, wychowania w rodzinie i funkcjonowania wyższych seminariów duchownych; 2) rozwiązywanie kwestii związanych z wydawaniem przez instytucje kościelne periodyków, książek i wielkości ich nakładów; 3) sprawy incydentalne, takie jak rozpatrywanie wniosków związanych z budownictwem sakralnym.

Biskup Dąbrowski zaproponował powołanie w ramach Komisji Wspólnej zespołów roboczych do zajęcia się określonymi tematami. Tak utworzone zespoły sporządzałyby protokoły, w których miały być wyszczególnione zagadnienia uzgodnione i nieuzgodnione oraz zamieszczone wnioski. Minister Kuberski zgodził się na przedstawione propozycje i postulował jednocześnie, aby uzgodnić sposób wnoszenia spraw na forum Komisji Wspólnej. Biskup wyszedł z inicjatywą, aby ks. Alojzy Orszulik i Aleksander Merker, sekretarze Komisji, odbywali spotkania celem ustalenia problematyki, która ma być podejmowana na kolejnych posiedzeniach tego gremium ${ }^{16}$.

\footnotetext{
${ }^{15}$ Bp B. Dąbrowski. Kopia Pro memoria. Warszawa, 08-10-1980. AKEP, sygn. III 0305.

${ }^{16}$ Sekretariat Konferencji Episkopatu Polski. Notatka z rozmowy Ks. Biskupa B. Dąbrowskiego i Ks. A. Orszulika z min. J. Kuberskim. Rozmowa odbyła się dnia
} 
W dniu 13 listopada 1980 r. ks. A. Orszulik przesłał zestawy tematów proponowanych przez stronę kościelną do podjęcia przez Komisję Wspólną. Zakres spraw miał być doprecyzowany w czasie najbliższego posiedzenia Komisji Wspólnej, planowanego na 20 i 21 listopada ${ }^{17}$. Zestaw zagadnień przedstawiony przez stronę kościelną składał się z trzydziestu pozycji, które można pogrupować w następujący sposób:

1. Osobowość publiczno-prawna Kościoła i uznanie kościelnych osób prawnych przez prawo państwowe, tematyka związana z dekretem Rady Państwa PRL z dnia 31 grudnia 1956 r. o organizowaniu i obsadzaniu stanowisk kościelnych, funkcjonowanie kościelnego związku „Caritas” oraz sprawy papieskich fakultetów teologicznych i Katolickiego Uniwersytetu Lubelskiego, a także możność wolnego komunikowania się duchowieństwa i wiernych ze Stolicą Apostolską;

2. Dostęp Kościoła do środków społecznego przekazu, działalność wydawnictw i drukarni kościelnych, swoboda Kościoła w katechizowaniu dzieci i młodzieży, wychowanie dzieci i młodzieży w szkołach, zakładach opiekuńczo-wychowawczych, w czasie obozów i kolonii, oraz prowadzenie duszpasterstwa w szpitalach, domach opieki i wojsku, tworzenie i status niższych i wyższych seminariów duchownych;

3. Miejsca święte, zgromadzenia religijne, procesje, pielgrzymki, budowa i lokalizacja obiektów sakralnych i cmentarzy;

4. Swobodne funkcjonowanie instytutów zakonnych i świeckich;

5. Prawa obywatelskie i praworządność, problemy moralności społecznej, trwałość rodziny, zwalczanie alkoholizmu;

6. Wolność religijna i tolerancja przekonań, funkcjonowanie organizacji kościelnych i katolickiego laikatu, szkół katolickich i zakładów wychowawczo-opiekuńczych oraz pomocy społecznej, nauki i kultury;

9.10.1980 r., godz. 9-11.30 w Urzędzie do Spraw Wyznań (bez daty). AKEP, sygn. III 0305, s. 1-4.

${ }^{17}$ Kopia pisma. Ks. A. Orszulik do J. Kuberskiego. Warszawa, 13-11-1980. AKEP, sygn. III 0305. 
7. Sprawy związane z majątkiem kościelnym;

8. Funkcjonowanie sanktuarium na Jasnej Górze w Częstochowie ${ }^{18}$.

Od listopada 1980 r. w skład Komisji Wspólnej przedstawicieli Rządu PRL i Episkopatu Polski weszli: kard. Franciszek Macharski, abp Jerzy Stroba, bp Bronisław Dąbrowski, ks. Alojzy Orszulik - ze strony kościelnej oraz: wicepremier Kazimierz Barcikowski, sekretarz KC PZPR Jerzy Kuberski, minister-kierownik Urzędu do Spraw Wyznań, poseł Witold Lipski, wiceprzewodniczący Komisji Spraw Zagranicznych Sejmu i Aleksander Merker, wicedyrektor Urzędu do Spraw Wyznań - ze strony rządowej ${ }^{19}$.

Drugie posiedzenie Komisji Wspólnej w 1980 r. odbyło się w dniach 20 i 21 listopada. Tym razem obradowano już w pełnym składzie. Strona rządowa przedstawiła aktualną sytuację społeczno-gospodarczą w kraju, co stało się swego rodzaju zwyczajem powtarzanym na kolejnych zebraniach Komisji. W trakcie obrad kard. Macharski wyraził nadzieję, że zostaną stworzone instytucjonalne zabezpieczenia przed powtarzającymi się konfliktami władzy ze społeczeństwem. Wskazał, że tematów do podjęcia na forum tego gremium jest bardzo wiele, ale głównym jest sprawa osobowości publiczno-prawnej Kościoła i jego instytucji, a to stworzy płaszczyznę prawną do nawiązania stosunków ze Stolicą Apostolską ${ }^{20}$.

Po dyskusji przyjęto plan pracy Komisji Wspólnej w oparciu o trzydzieści tematów przedstawionych przez stronę kościelną i uzupełnionych o następujące zagadnienia przedstawione przez stronę rządową: rozszerzenie punktu dotyczącego całokształtu funkcjonowania seminariów duchownych, dodanie tematu dotyczącego zatrudniania przez instytucje kościelne świeckich absolwentów Akademii

\footnotetext{
${ }^{18}$ Sekretariat Konferencji Episkopatu Polski. Tematy na Komisję Wspólną. Warszawa, 13-11-1980. AKEP, sygn. III 0305.

${ }^{19}$ Protokół z posiedzenia Komisji Wspólnej przedstawicieli Rządu PRL i Episkopatu Polski w dniach 20 i 21 listopada 1980 r. Warszawa, 21-11-1980 (podpisany przez wszystkich członków Komisji Wspólnej). AKEP, sygn. III 03050, s. 1.

20 Tamże, s. 1-2.
} 
Teologii Katolickiej i wydziałów kościelnych Katolickiego Uniwersytetu Lubelskiego, z zastrzeżeniem, że lista spraw pozostanie otwarta. Zaakceptowano też jako zasadę, że projekt planu posiedzeń będzie opracowywany przez Sekretariat Konferencji Episkopatu i Urząd do Spraw Wyznań, a także, że w przypadku absencji członka Komisji Wspólnej (z wyjątkiem przewodniczącego), każda ze stron, w przypadku nieobecności członka, będzie mogła dokooptować na poszczególne posiedzenie jego zastępcę ${ }^{21}$.

W punkcie dotyczącym uznania osobowości publiczno-prawnej Kościoła, strona rządowa podkreśliła, że obowiązująca Konstytucja PRL uznaje istnienie Kościoła i należy szukać formuły prawnej dla opisania tej rzeczywistości. Przedstawiciele Episkopatu podkreślili, że Kościół i instytucje kościelne, w aktualnie obowiązującym prawie polskim, nie są uznawane. W konkluzji zgodzono się na powołanie podkomisji, która będzie miała za zadanie opracowanie formuły deklaracji prawnej stron i przedstawienie jej Komisji Wspólnej22.

W sprawie Papieskich Fakultetów Teologicznych w Krakowie, Wrocławiu, Poznaniu i Warszawie zgodzono się, że w ciągu roku będą wydane akty prawne, na mocy których zostaną prawnie uznane wymienione fakultety. Uzgodniono też, że kwestia włączenia do systemu ubezpieczenia społecznego pracowników tam zatrudnionych będzie załatwiona w najbliższym czasie, a także, że Urząd do Spraw Wyznań wyda odpowiednie akty prawne, aby instytucje te stały się podmiotem prawa i mogły nabywać nieruchomości. Postanowiono, że niezwłocznie cenzura zaprzestanie skreślania informacji o tych fakultetach. Natomiast sprawa uznawania stopni i tytułów akademickich będzie dalej konsultowana i formalna decyzja zapadnie w ciągu $\mathrm{roku}^{23}$.

Komisja Wspólna postanowiła powołać podkomisję do rozpatrzenia spraw wydawnictw i czasopism kościelnych oraz katolickich. W tej

\footnotetext{
${ }^{21}$ Tamże, s. 2-3. Możliwości uczestniczenia w obradach Komisji Wspólnej zastępcy członka żadna ze stron nie wykorzystała w latach 1980-1981.

${ }^{22}$ Tamże, s. 3-4.

${ }^{23}$ Tamże, s. 4.
} 
sprawie ustalono, że: 1) wydawnictwa będą swobodnie ustalać plan i dysponować przydzielonym papierem, 2) „Tygodnik Powszechny” otrzyma wysokość nakładu 50 tys. egzemplarzy, 3) wyrażono zgodę na wydawanie czasopisma "Communio” na papierze z przydziału państwowego, 4) w drodze indywidualnych decyzji będą udzielane zwolnienia podatkowe od papieru przywożonego z zagranicy, 5) podręczniki do nauki religii i katechizmy będą wydawane przez poszczególne wydawnictwa oraz będzie możliwe przekazywanie papieru drukarskiego między nimi, 6) będzie możliwe nabywanie przez instytucje kościelne używanych maszyn poligraficznych i sprowadzanie nowych z zagranicy ${ }^{24}$. Komisja Wspólna zadecydowała o powołaniu podkomisji złożonej z przedstawicieli Komisji Konferencji Episkopatu do Spraw Trzeźwości, wiceministra zdrowia i opieki społecznej, wiceministra oświaty i wychowania, prezesa Głównego Społecznego Komitetu Przeciwalkoholowego, w celu omówienia całokształtu działań i utworzenia struktur organizacyjnych niezbędnych do przeciwdziałania uzależnieniu alkoholowemu obywateli ${ }^{25}$. Kolejną podkomisją, którą wówczas utworzono, była do Spraw Wyższych Seminariów Duchownych, ze szczególnym uwzględnieniem rozwiązania problemu powoływania kleryków do odbycia zasadniczej służby wojskowej. Ze

\footnotetext{
${ }^{24}$ Tamże, s. 6. Strona kościelna w Przedłożeniu przygotowanym na posiedzenie Komisji Wspólnej wniosła o podwyższenie nakładu wydawniczego następujących czasopism: „Tygodnik Powszechny” (Kraków) z 40 tys. egz. do 200 tys. egz., „Gość Niedzielny” (Katowice), z 90 tys. egz. do 200 tys. egz., „Przewodnik Katolicki” (Poznań), do 200 tys. egz., „Msza Święta” (Towarzystwo Chrystusowe), z 15.5 tys. egz. do 25.5 tys. egz., „W drodze” (dominikanie), z 3.5 tys. egz. do 20 tys. egz., „Ateneum Kapłańskie” (Włocławek), z 4 tys. egz. do 6 tys. egz. Przedstawiciele Episkopatu zwrócili się z prośbą o reaktywowanie między innymi następujących czasopism: „Niedziela” (Częstochowa), do 100 tys. egz., „Rycerz Niepokalanej” (franciszkanie - Niepokalanów), do 1000 tys. egz., „Posłaniec Serca Jezusowego” (jezuici - Kraków), do 150 tys. egz., „Królowa Apostołów” (pallotyni), do 50 tys. egz. Przedłożenie. Komisja Wspólna 20 i 21 listopada 1980 r. Warszawa, 19-11-1980. AKEP, sygn. III 0305, s. 9-11.

${ }^{25}$ Protokół z posiedzenia Komisji Wspólnej przedstawicieli Rządu PRL i Episkopatu Polski w dniach 20 i 21 listopada 1980 r. Warszawa, 21-11-1980 (podpisany przez wszystkich członków Komisji Wspólnej). AKEP, sygn. III 03050, s. 7.
} 
strony Episkopatu w jej skład miał wejść bp Lech Kaczmarek jako przewodniczący strony kościelnej ${ }^{26}$.

W sprawie obowiązującego dekretu Rady Państwa PRL z dnia 31 grudnia 1956 r. o organizowaniu i obsadzaniu stanowisk kościelnych ${ }^{27}$ wypowiedział się bp B. Dąbrowski, który podkreślił, że od wejścia w życie tego aktu prawnego, strona kościelna niezmiennie domagała się jego uchylenia. Sekretarz Konferencji Episkopatu Polski zaznaczył, że Dekret był i jest narzędziem walki z Kościołem i utrudnia normalizację wzajemnych stosunków. Strona rządowa stwierdziła, że kwestia ta wymaga zmian i należy ją przekazać do zespołu, który ma zająć się statusem prawnym Kościoła, czyli do podkomisji powołanej na tym posiedzeniu ${ }^{28}$.

Ostatnie zebranie Komisji Wspólnej w 1980 r. odbyło się 8 grudnia. $\mathrm{W}$ jego trakcie omówiono sprawy związane $\mathrm{z}$ wychowaniem dzieci i młodzieży w szkołach i zakładach opiekuńczo-wychowawczych, na koloniach, zimowiskach i obozach. Strona kościelna podkreśliła konieczność respektowania wolności sumienia i wyznania, gdyż w przeszłości te podstawowe prawa były wielokrotnie łamane. Zgodzono się na powołanie zespołu roboczego, który zająłby się przedstawianymi

\footnotetext{
${ }^{26}$ Tamże, s. 7-8.

${ }^{27}$ Więcej na temat konsekwencji obowiązywania tego aktu prawnego zobacz: M. StęPIEŃ, Działania Konferencji Episkopatu Polski podejmowane w latach pięćdziesiątych w związku z dekretem Rady Państwa PRL z dnia 31 grudnia 1956 r. o organizowaniu i obsadzaniu stanowisk kościelnych, Warszawskie Studia Pastoralne VIII 20 (2013) nr 3, s. 283-300; M. STĘPIEŃ, Działania Konferencji Episkopatu Polski podejmowane w latach sześćdziesiątych $w$ związku z dekretem Rady Państwa PRL $z$ dnia 31 grudnia 1956 r. o organizowaniu i obsadzaniu stanowisk kościelnych, Warszawskie Studia Pastoralne VIII 20 (2013) nr 3, s. 301-325; M. STęPIEŃ, Działania Konferencji Episkopatu Polski podejmowane w latach siedemdziesiatych $w$ zwiazku $z$ dekretem Rady Państwa PRL z dnia 31 grudnia 1956 r. o organizowaniu i obsadzaniu stanowisk kościelnych, Warszawskie Studia Pastoralne IX 22 (2014) nr 1, s. 363-390.

${ }^{28}$ Protokół z posiedzenia Komisji Wspólnej przedstawicieli Rządu PRL i Episkopatu Polski w dniach 20 i 21 listopada 1980 r. Warszawa, 21-11-1980 (podpisany przez wszystkich członków Komisji Wspólnej). AKEP, sygn. III 03050, s. 8.
} 
zagadnieniami ${ }^{29}$. Komisja Wspólna ustaliła skład osobowy powołanych zespołów roboczych ${ }^{30}$. Do Zespołu Roboczego do Spraw Seminariów Duchownych weszli: Czesław Banach, podsekretarz stanu w Ministerstwie Oświaty i Wychowania, Janusz Stęperski, dyrektor departamentu w Ministerstwie Nauki, Szkolnictwa Wyższego i Techniki, Aleksander Merker i Janina Misiuro z Urzędu do Spraw Wyznań - ze strony rządowej oraz bp Lech Kaczmarek, ks. Franciszek Gościński, zastępca sekretarza Konferencji Episkopatu, ks. doc. Kazimierz Romaniuk, ks. dr Władysław Bomba i ks. Tadeusz Gocłowski - ze strony Konferencji Episkopatu Polski ${ }^{31}$. W skład Zespołu Roboczego do Walki z Alkoholizmem i Wychowania do Trzeźwości weszli: Ryszard Brzozowski, podsekretarz stanu w Ministerstwie Zdrowia i Opieki Społecznej i jednocześnie prezes Zarządu Głównego Polskiego Czerwonego Krzyża, Jerzy Wojciechowski, podsekretarz stanu w Ministerstwie Oświaty i Wychowania, Kazimierz Kukawka, przewodniczący Głównego Społecznego Komitetu Przeciwalkoholowego, Alicja Sadownik z Urzędu do Spraw Wyznań - ze strony rządowej oraz bp Jan Mazur, ordynariusz diecezji siedleckiej i przewodniczący Komisji Episkopatu do Spraw Trzeźwości, bp Zygmunt Kamiński, prof. Andrzej Święcicki i ks. Henryk Korża - ze strony Konferencji Episkopatu Polski ${ }^{32}$. Postanowiono, aby Sekretariat Konferencji Episkopatu Polski i Urząd do Spraw Wyznań omówili skład

\footnotetext{
${ }^{29}$ Protokół z posiedzenia Komisji Wspólnej przedstawicieli Rządu i Episkopatu w dniu 8 grudnia 1980 r. Warszawa, 08-12-1980 (podpisany przez wszystkich członków Komisji Wspólnej). AKEP, sygn. III 03050, s. 4-6.

${ }^{30}$ W Protokole z posiedzenia Komisji Wspólnej z 8 grudnia 1980 r. użyto terminu „zespół roboczy”, na określenie grupy eksperckiej utworzonej przez Komisję Wspólną, natomiast w Protokole z posiedzenia Komisji Wspólnej w dniach 20 i 21 listopada 1980 r. używano terminu „podkomisje”. Wszystkie grupy eksperckie powołane przez Komisję Wspólną finalnie określono jako „zespoły robocze”, a nie "podkomisje”.

${ }^{31}$ Protokół z posiedzenia Komisji Wspólnej przedstawicieli Rządu i Episkopatu w dniu 8 grudnia 1980 r. Warszawa, 08-12-1980 (podpisany przez wszystkich członków Komisji Wspólnej). AKEP, sygn. III 03050, s. 10.

${ }^{32}$ Tamże, s. 10-11.
} 
osobowy zespołów roboczych, do Spraw Wydawnictw, do Spraw Wychowania i Zespołu Prawnego ${ }^{33}$.

Rozpatrywanie spraw przez Komisję Wspólną zostało przyśpieszone w $1981 \mathrm{r}$. W trakcie posiedzenia w styczniu omawiano kwestię Kościelnego Związku „Caritas”. Z racji prezentowanych rozbieżnych stanowisk strony ustaliły powołanie nieformalnego zespołu, w celu bardziej szczegółowego przeanalizowania spraw, w którego skład weszli: bp B. Dąbrowski, ks. A. Orszulik, min. J. Kuberski, T. Dusik ${ }^{34}$. Na tym samym zebraniu zajęto się też kwestiami dotyczącymi: aktualnej sytuacji w kraju, świeckiego charakteru państwa, w odniesieniu do pluralizmu światopoglądowego społeczeństwa, a także swobody Kościoła w organizowaniu i prowadzeniu katechizacji dzieci i młodzieży. W tych punktach strony przedstawiły swoje stanowiska i nie podjęto żadnych wiążących decyzji ${ }^{35}$.

W sprawach organizacyjnych powołano składy osobowe trzech zespołów roboczych. Do Zespołu Roboczego do Spraw Legislacyjnych weszli: prof. dr Adam Łopatka, dyrektor Instytutu Państwa i Prawa PAN, prof. dr Michał Pietrzak (Uniwersytet Warszawski), Aleksander Merker, wicedyrektor Urzędu do Spraw Wyznań, Bogusław Skręta z Urzędu do Spraw Wyznań - ze strony Rządu PRL oraz ks. Alojzy Orszulik, ks. prof. dr Marian Żurowski (Akademia Teologii Katolickiej w Warszawie), prof. dr Andrzej Stelmachowski (Uniwersytet Warszawski), ks. dr Jan Chmiel, Sekretariat Konferencji Episkopatu Polski - ze strony kościelnej. W Zespole Roboczym do Spraw Wydawnictw i Czasopism znalazły się następujące osoby: Stanisław Puchała, podsekretarz stanu w Ministerstwie Kultury i Sztuki, dr Aleksander Skarżyński, dyrektor Naczelnego Zarządu Wydawnictw, Jan Kluczek, dyrektor naczelny Zjednoczenia Przemysłu Poligraficznego, red. Jan Czapczyński, z Biura Rzecznika Prasowego Rządu, nacz. Jerzy Janitz,

\footnotetext{
${ }^{33}$ Tamże, s. 11.

${ }^{34}$ Protokół z posiedzenia Komisji Wspólnej przedstawicieli Rządu PRL i Episkopatu Polski w dniu 10 stycznia 1981 r. Warszawa, 10-01-1981 (podpisany przez wszystkich członków Komisji Wspólnej). AKEP, sygn. III 03050, s. 5-6.

${ }^{35}$ Tamże, s. 1-4, 6-16.
} 
z Urzędu do Spraw Wyznań - z ramienia Rządu PRL oraz bp Herbert Bednorz, prof. dr Jacek Woźniakowski, dyrektor Społecznego Instytutu Wydawniczego „Znak”, ks. Stefan Dusza, dyrektor Wydawnictwa „Pallotinum”, ks. Marian Maciołka, dyrektor Wydawnictwa „Księgarnia św. Wojciecha”, dr Irena Mierzwa, z Wydawnictwa „Księgarnia św. Jacka" - ze strony Konferencji Episkopatu Polski. Do Zespołu Roboczego do Spraw Wychowania weszli: ze strony rządowej - Bolesław Dylak, podsekretarz stanu w Ministerstwie Oświaty i Wychowania, Eugeniusz Pietrasik, dyrektor departamentu w Ministerstwie Nauki, Szkolnictwa Wyższego i Techniki, doc. dr. Stanisław Frycie, dyrektor Instytutu Programów Szkolnych, Alicja Sadownik, z Urzędu do Spraw Wyznań; ze strony kościelnej: bp Edward Materski, ks. Franciszek Gościński, zastępca sekretarza Konferencji Episkopatu Polski, ks. prał. Stefan Piotrowski, wikariusz generalny archidiecezji warszawskiej, ks. dr Marian Jakubiec i ks. prof. dr Józef Tischner ${ }^{36}$.

Następne obrady Komisji Wspólnej odbyły się w dniu 2 marca 1981 r. W trakcie zebrania przedyskutowano zagadnienie dostępu Kościoła do środków społecznego przekazu. Strona rządowa podkreśliła, że w nowym projekcie ustawy o cenzurze wydawnictwa religijne nie będą podlegać tej kontroli ${ }^{37}$. Zajęto się też kwestiami dotyczącymi duszpasterstwa w szpitalach, państwowych domach opieki, domach wypoczynkowych, zakładach poprawczych i peni-

\footnotetext{
${ }^{36}$ Tamże, s. 16-17.

${ }^{37}$ Protokół z posiedzenia Komisji Wspólnej przedstawicieli Rządu i Episkopatu w dniu 2 marca 1981 r. Warszawa, 02-03-1981 (podpisany przez wszystkich członków Komisji Wspólnej). AKEP, sygn. III 03050, s. 1, 4-11. Strony zaaprobowały następujący zapis w projekcie ustawy dotyczący wyłączenia spod ingerencji cenzury: „Zaaprobowane przez Kościół Katolicki oraz inne związki wyznaniowe: pisma, obrazy i nagrania o charakterze przekazu wiary, dokumenty, teksty liturgiczne, teologiczne, zakonne modlitewne, katechetyczne i duszpasterskie, teksty prawa kościelnego, zawiadomienia i informatory, transmisje obrzędów religijnych w audycjach radiowych i telewizyjnych, imprezy kulturalno-religijne organizowane na terenie kościelnym, listy i pisma okólne do użytku wewnętrznego instytucji kościelnych oraz przeznaczone na użytek służbowy druki, formularze i inne dokumenty”. Ustalono, że przez „pismo okólne” rozumie się biuletyny i wiadomości diecezjalne. Tamże, s. 11.
} 
tencjarnych. W sprawach bieżących, między innymi, podjęto kwestię uregulowania własności nieruchomości kościelnych. Strona rządowa poinformowała, że minister-kierownik Urzędu do Spraw Wyznań w dniu 16 lutego 1981 r. wydał Pismo Okólne do wojewodów, uzgodnione wcześniej z Sekretariatem Konferencji Episkopatu Polski ${ }^{38}$. Komisja Wspólna wyraziła zgodę na reaktywowanie w Katolickim Uniwersytecie Lubelskim Wydziału Nauk Społecznych, a strona rządowa zgodziła się na przedłużanie ważności paszportów przez Ambasadę PRL w Rzymie, księżom i członkom zakonów, bez każdorazowego zwracania się w tych sprawach do centrali ${ }^{39}$.

Trzecie z kolei obrady w 1981 r. odbyły się w dniu 1 kwietnia. Na wstępie posiedzenia przedstawiciele rządu poinformowali o wyrażeniu zgody na rozbudowę domu „Księżówka” w Zakopanem ${ }^{40}$. Zasadniczymi punktami, które podjęto, były te, dotyczące umożliwienia swobodnej działalności instytutów zakonnych i świeckich ${ }^{41}$ oraz budowy i lokalizacji obiektów sakralnych i kościelnych, jak

${ }^{38}$ Tamże, s. 11-15, 17. Punkt 5 Pisma Okólnego skierowanego do wojewodów brzmiał następująco: „W przypadkach, gdy nieruchomości będące we faktycznym władaniu parafii katolickich, są własnością osób fizycznych, mogą one zostać w trybie prawem przepisanym, przeniesione na własność parafii”. Natomiast pkt 9 pozwalał na nabywanie nieruchomości niezbędnych w przyszłości, przed zatwierdzeniem inwestycji. Tamże, s. 17

${ }^{39}$ Tamże.

${ }^{40}$ Protokół z posiedzenia Komisji Wspólnej przedstawicieli Rządu i Episkopatu w dniu 1 kwietnia 1981 r. Warszawa, 01-04-1981 (podpisany przez wszystkich członków Komisji Wspólnej). AKEP, sygn. III 03050. W czasie 180. Zebrania Plenarnego Konferencji Episkopatu Polski, które obradowało w Gnieźnie w dniach 14 i 15 września 1980 r., biskupi zostali poinformowani, że wojewoda nowosądecki wydał zgodę na rozbudowę „Księżówki” w Zakopanem. Już wcześniej zgodę na rozbudowę tego obiektu biskupi wyrazili w drodze uchwały podczas 177. Zebrania Plenarnego, które obradowało w Warszawie 11 i 12 grudnia 1980 r. Zob. Uchwały Konferencji Plenarnych Episkopatu Polski 1946-1989. Wykaz Konferencji Plenarnych Episkopatu Polski. AKEP, sygn. Archiwum 1945-1968 (skrót: I) 0130/III, s. VI 6; por. Uchwały Konferencji Plenarnych Episkopatu Polski 1946-1989. Teksty uchwał Konferencji Plenarnych Episkopatu według działów. AKEP, sygn. I 0130/III, poz. III 19/3-4.

${ }^{41}$ Zob. Sekretariat Konferencji Episkopatu Polski. Komisja Wspólna 1 kwietnia 1981 r. Przedłożenia na temat: Swoboda działania instytutów zakonnych i instytutów 
też zakładania cmentarzy. Przedstawiciele Episkopatu przedłożyli obszerne i szczegółowe postulaty. Strony zgodziły się, aby w tych kwestiach upoważnić bpa B. Dąbrowskiego i min. J. Kuberskiego do szczegółowego omówienia zagadnień i zaprezentowania wniosków Komisji Wspólnej ${ }^{42}$. W sprawach bieżących zajęto się kwestią uczelni wyższych, a także niższymi i wyższymi seminariami duchownymi oraz katechizacją i wychowaniem młodzieży. Dyskutowano o nadawaniu stopni i tytułów naukowych. Strona kościelna postulowała wyłączenie wyższych uczelni kościelnych z ustawy o szkolnictwie wyższym. W tym kontekście głównie chodziło o papieskie wydziały teologiczne. Na zakończenie obrad przyjęto propozycję rozszerzenia składu osobowego Zespołu Roboczego do Spraw Legislacji o jedną osobę z każdej ze stron. Z ramienia Episkopatu zgodzono się na wejście do tego zespołu bpa Józefa Glempa ${ }^{43}$.

Następne posiedzenie Komisji Wspólnej odbyło się w dniu 15 maja 1981 r. Ponownie omawiano sytuację społeczno-gospodarczą kraju i problem zapewnienia swobody działalności charytatywnej Kościoła. Przedstawiciele Episkopatu zgodzili się, aby nie rozwiązywać Zrzeszenia Katolików „Caritas”, natomiast strona rządowa wyraziła akceptację, by Kościół posiadał stosowną organizację do prowadzenia działalności charytatywnej. Strona kościelna sprzeciwiła się, aby w nazwach obu organizacji występował termin „Caritas”. Następnie podsumowano dotychczasową działalność powołanych przez Komisję Wspólną zespołów roboczych. Konkluzja przedstawicieli Episkopatu sprowadzała się do stwierdzenia, że zespoły te działają w sposób powolny, a wynika to z postawy przedstawicieli rządu. W końcowej

świeckich zgodnie z ich zadaniami określonymi w konstytucjach zatwierdzonych przez władze kościelne. Warszawa, 27-03-1981. AKEP, sygn. III 0305.

${ }^{42}$ Protokół z posiedzenia Komisji Wspólnej przedstawicieli Rządu i Episkopatu w dniu 1 kwietnia 1981 r. Warszawa, 01-04-1981 (podpisany przez wszystkich członków Komisji Wspólnej). AKEP, sygn. III 03050, s. 6-20.

${ }^{43}$ Tamże, s. 21-25. 
części obrad strony ustaliły, że do Zespołu Roboczego do Spraw Legislacji zostaną dołączeni bp Józef Glemp i prof. Jerzy Jodłowski ${ }^{44}$.

Po upływie ponad miesiąca odbyło się kolejne posiedzenie Komisji Wspólnej. W dniu 23 czerwca 1981 r. zajmowano się wstępnym omówieniem rewindykacji obiektów i gruntów kościelnych. Strona rządowa zgodziła się z poglądem, że gdzie jest możliwe, to należy zwrócić nieruchomości, jednak pozostaje kwestia trybu prawnego dokonania zwrotów. Komisja Wspólna zapoznała się z informacjami o pracach zespołów roboczych. Zakres działania Zespołu Roboczego do Spraw Seminariów rozszerzono o szkolnictwo wyższe. W sprawach bieżących strona rządowa poinformowała o pracach nad projektem dokumentu uchylającego tzw. Okólnik nr 3. Według przedstawicieli Episkopatu, w latach 1982-1986 istniała potrzeba zbudowania ok. 700 kościołów i kaplic ${ }^{45}$. Zespół Roboczy do Spraw Walki z Alkoholizmem i Wychowania w Trzeźwości przyjął następujący projekt zapisu, który miał znaleźć się w nowej ustawie antyalkoholowej: „1. Działalność trzeźwościową mogą prowadzić towarzystwa organizowane wyłącznie w tym celu przez Kościół Rzymskokatolicki, oraz inne kościoły i związki wyznaniowe, prawnie uznane przez Państwo. 2. Towarzystwa, o których mowa w ust. 1 nie podlegają przepisom prawa o stowarzyszeniach zaś nadzór nad ich działalnością sprawują władze kościołów lub związków wyznaniowych”. Na sugestię strony kościelnej wykreślono z tekstu w ust. 1 słowo „wyłącznie”, a słowo „Rzymskokatolicki”, zastąpiono słowem „katolicki”. Tekst z poprawkami został zaakceptowany przez Komisję Wspólną ${ }^{46}$. Zgodzono się na propozycję strony kościelnej, aby w tzw. sprawie „Caritas” zorganizować trójstronne zebranie przedstawicieli Urzędu do Spraw Wyznań, Episkopatu i Zrzeszenia Katolików oraz wyrażono zgodę

\footnotetext{
${ }^{44}$ Protokół z posiedzenia Komisji Wspólnej przedstawicieli Rządu i Episkopatu w dniu 15 maja 1981 r. Warszawa, 15-05-1981 (podpisany przez wszystkich członków Komisji Wspólnej). AKEP, sygn. III 03050.

${ }^{45}$ Protokół z posiedzenia Komisji Wspólnej przedstawicieli Rządu i Episkopatu w dniu 23 czerwca 1981 r. Warszawa, 23-06-1981 (podpisany przez wszystkich członków Komisji Wspólnej). AKEP, sygn. III 03050, s. 1-12.

${ }^{46}$ Tamże, s. 12-13.
} 
na utworzenie drukarni i wydawnictwa przez Konferencję Episkopatu Polski, jak też na nabycie działek i wybudowanie odpowiedniej infrastruktury ${ }^{47}$.

W czasie posiedzenia Komisji Wspólnej w dniu 27 sierpnia 1981 r. zajmowano się kwestiami dotyczącymi duszpasterstwa w wojsku, wolnością sprawowania kultu i zgromadzeń religijnych. Strona rządowa zadeklarowała, że uznaje do załatwienia przedstawione sprawy, ale są to kwestie delikatne i wymagające czasu. Dokonano przeglądu zaawansowania prac Zespołów Roboczych: do Spraw Budownictwa Sakralnego, do Spraw Duszpasterstwa w Zakładach Karnych i Zakładach Służby Zdrowia, do Spraw Czasopism, do Spraw Wychowania ${ }^{48}$.

W czasie październikowego posiedzenia Komisji Wspólnej omawiano kwestie dotyczące nauki i kultury, organizacji kościelnych, $\mathrm{w}$ aspekcie prawnym ich istnienia i funkcjonowania, sprawę „Caritas” oraz, jak stało się to już zwyczajem, strona rządowa przedstawiła informacje o aktualnej sytuacji w kraju. Przedstawiono także zaawansowanie prac zespołów roboczych ${ }^{49}$. Strona kościelna w sprawie nauki i kultury przedstawiła swoje postulaty. Stwierdzono, że podstawowym warunkiem jest wolność kultury i nauki, a Kościół potwierdza autonomię w tych dziedzinach. Każdy człowiek ma prawo szukać prawdy i głosić własne opinie. Podkreślono, że w programach nauki szkolnej i studiów musi być uwzględniony pełny obraz kultury polskiej, w tym także nurt religijny ${ }^{50}$. Odniesiono się też do funkcjonowania organizacji kościelnych, zwracając uwagę, że ich rola w życiu Kościoła i społeczeństwa jest ugruntowana, natomiast status prawny w systemie prawa państwowego nie jest unormowany. Chodziło tu przede wszystkim o funkcjonowanie stowarzyszeń koś-

\footnotetext{
${ }^{47}$ Tamże, s. 13, 16.

${ }^{48}$ Protokół z posiedzenia Komisji Wspólnej przedstawicieli Rządu i Episkopatu w dniu 27 sierpnia 1981 r. Warszawa, 27-08-1981 (podpisany przez wszystkich członków Komisji Wspólnej). AKEP, sygn. III 03050.

${ }^{49}$ Protokół z posiedzenia Komisji Wspólnej przedstawicieli Rządu i Episkopatu w dniu 9 października 1981 r. Warszawa, 09-10-1981 (podpisany przez wszystkich członków Komisji Wspólnej). AKEP, sygn. III 03050.

${ }^{50}$ Tamże, s. 10-14.
} 
cielnych. Przedstawiciele Episkopatu podkreślili, że obowiązujący stan prawny dotyczący organizacji i stowarzyszeń kościelnych jest niezgodny z podstawowymi prawami człowieka. Strona rządowa poinformowała, że w planowanych zmianach legislacyjnych będzie przewidziany odrębny tryb uznawania organizacji religijnych sensu stricto. Dalsze rozpatrywanie tej sprawy przekazano do Zespołu Roboczego do Spraw Legislacji ${ }^{51}$.

Kolejnym omawianym zagadnieniem była sprawa „Caritas”. Zostały ustalone poszczególne etapy załatwiania tej kwestii. Uzgodniono, że ze strony Kościoła będą funkcjonowały „Caritas” diecezjalne, a Ogólnopolska Rada zajmie się koordynacją działań. Urząd do Spraw Wyznań podejmie rozmowy z dotychczasowym Zrzeszeniem Katolików „Caritas” w sprawie nowej nazwy dla tej instytucji. Zgodzono się, że nazwa "Caritas” będzie przysługiwać wyłącznie charytatywnym instytucjom kościelnym. Strona rządowa podkreśliła, że statuty tych instytucji powinny być obopólnie uzgodnione ${ }^{52}$.

Komisja Wspólna z zadowoleniem przyjęła informację z dwóch obszarów: o zakończeniu rozmów roboczych z Ministerstwem Sprawiedliwości, w efekcie których zostały wydane zarządzenia ministra, regulujące sprawy związane z posługą religijną $\mathrm{w}$ zakładach karnych i zakładach poprawczych oraz w wyniku negocjacji w Ministerstwie Zdrowia i Opieki Społecznej wydana została instrukcja o posługach religijnych w zakładach służby zdrowia i opieki społecznej. Z satysfakcją przyjęto ustalenie, że niższe seminaria duchowne uzyskają te same uprawnienia, jakie posiadają licea ogólnokształcące prowadzone przez instytucje kościelne ${ }^{53}$.

Ostatnie posiedzenie Komisji Wspólnej w roku 1981 odbyło się 23 listopada, które głównie poświęcone było sytuacji w kraju oraz podsumowaniu działania Komisji i aktualnemu stanu załatwiania problemów omawianych przez Komisję i zespoły robocze. W czasie tych

\footnotetext{
51 Tamże, s. 15-18.

${ }^{52}$ Tamże, s. 19-20.

${ }^{53}$ Komunikat z posiedzenia Komisji Wspólnej przedstawicieli Rządu i Episkopatu w dniu 9 października 1981 r. Warszawa, 09-10-1981. AKEP, sygn. III 03050.
} 
obrad nie podjęto zasadniczych decyzji, a w rozpatrywanych punktach powtarzano, że niezbędne są kolejne konsultacje i rozmowy ${ }^{54}$.

\section{Rozmowy i wymiana korespondencji prowadzone przez przedstawicieli Konferencji Episkopatu Polski z władzami PRL}

W omawianym okresie, do kontaktów dochodziło między bpem Bronisławem Dąbrowskim, sekretarzem Konferencji Episkopatu Polski, a najpierw Stanisławem Kanią, sekretarzem KC PZPR i jednocześnie upoważnionym do prowadzenia rozmów z Kościołem, a od jesieni 1980 r. z Kazimierzem Barcikowskim ${ }^{55}$, który wówczas przejął te obowiązki, gdyż Stanisław Kania został wybrany na pierwszego sekretarza KC PZPR oraz każdorazowym ministrem-kierownikiem Urzędu do Spraw Wyznań ${ }^{56}$. Systematycznie strony wymieniały się też korespondencją.

W końcu lutego 1980 r., w czasie Zebrania Plenarnego Konferencji Episkopatu Polski, bp Dąbrowski poinformował biskupów o rozmowach i wymianie korespondencji z przedstawicielami władz PRL. $\mathrm{W}$ styczniu tego roku spotkał się on $\mathrm{z}$ gen. B. Stachurą $\mathrm{w}$ sprawie indagacji alumnów wyższych seminariów duchownych przez funkcjonariuszy Służby Bezpieczeństwa, ze szczególnym uwzględnieniem przypadków mających miejsce przy okazji poboru do odbycia zasadniczej służby wojskowej ${ }^{57}$. Sekretarz Konferencji Episkopatu Polski zwrócił się z pismem do premiera Piotra Jaroszewicza z pro-

\footnotetext{
${ }^{54}$ Protokół z posiedzenia Komisji Wspólnej przedstawicieli Rządu i Episkopatu w dniu 23 listopada 1981 r. Warszawa, 23-11-1981 (podpisany przez wszystkich członków Komisji Wspólnej). AKEP, sygn. III 03050.

${ }^{55}$ Do rozmów bpa Bronisława Dąbrowskiego z Kazimierzem Barcikowskim głównie dochodziło na forum obrad Komisji Wspólnej przedstawicieli rządu PRL i Episkopatu Polski.

${ }^{56}$ Zob. Bp B. Dąbrowski. Kopia Pro memoria dla Pana Stanisława Kani, Sekretarza KC PZPR. Warszawa, 07-02-1980. AKEP, sygn. III 0200. Kazimierz Barcikowski w 1980 r. był wiceprezesem Rady Ministrów. Po zmianie kierownictwa PZPR, we wrześniu i październiku tego roku, Barcikowski został członkiem Rady Państwa i sekretarzem KC PZPR.

${ }^{57}$ Bp B. Dąbrowski. Pro memoria na 172. Konferencję Plenarną Episkopatu Warszawa, 27-28.II.1980 r. Warszawa, 27-02-1980. AKEP, sygn. III 013.
} 
pozycją określenia stawki ZUS w wysokości 18\% dla osób duchowych i zatrudnionych przez instytucje kościelne, co zostało zaakceptowane przez stronę rządową. W korespondencji z min. Kazimierzem Kąkolem, kierownikiem Urzędu do Spraw Wyznań, przesłał wykaz spraw wymagających załatwienia, w tym problematyki wydawnictw kościelnych, poboru alumnów wyższych seminariów duchownych do odbycia zasadniczej służby wojskowej. W ostatniej kwestii minister, odpowiadając wprost, stwierdził, że władze stosują odpowiedzialność zbiorową za negatywną postawę ordynariuszy. W ślad za korespondencją bpa Dąbrowskiego, min. Kąkol przedstawił wykaz spraw do załatwienia, w którym umieścił: łamanie prawa poprzez nielegalne budownictwo, wrogie politycznie homilie biskupów i działalność polityczna duchownych, odprawianie nabożeństw w punktach katechetycznych ${ }^{58}$. Biskup Dąbrowski poinformował biskupów, że ogłoszono ustawę Kodeks postępowania administracyjnego, w którym nie została uwzględniona propozycja strony kościelnej o konieczności uzasadnienia każdej decyzji administracyjnej, a także, że prawdopodobnie od 1 kwietnia wszyscy pracownicy instytucji kościelnych, w tym zakonnych, będą podlegali ubezpieczeniu społecznemu, ze składką w wysokości 18 proc. ${ }^{59}$ Sprawa ta została załatwiona na mocy Okólnika dotyczącego ubezpieczeń społecznych wydanego ostatniego dnia marca 1980 r., z dniem obowiązywania od 1 kwietnia. W dniu 31 marca 1980 r. bp Bronisław Dąbrowski wystosował pismo do Stanisława Kani, sekretarza KC PZPR, w sprawie postulowanego zawieszenia zasadniczej służby wojskowej alumnów wyższych seminariów duchownych ${ }^{60}$. Sprawa ta wówczas nie została pozytywnie załatwiona, gdyż strona kościelna podnosiła ją na obradach Komisji Wspólnej przedstawicieli Rządu PRL i Episkopatu od jesieni 1980 r.

W lecie 1980 r. doszło w Polsce do niepokojów społecznych. We wrześniu tego roku nastąpiły zmiany osobowe na najwyższych

\footnotetext{
${ }^{58}$ Tamże.

${ }^{59}$ Tamże.

${ }^{60}$ Podpisana kopia pisma. Bp B. Dąbrowski do bpa L. Kaczmarka. Warszawa, 6-05-1980. AKEP, sygn. III 013.
} 
szczeblach PZPR i Rządu PRL. W dniu 6 września 1980 r. bp Bronisław Dąbrowski spotkał się z wysłannikiem władz PRL Jerzym Kuberskim, ministrem-kierownikiem Urzędu do Spraw Wyznań, który zapewnił go w imieniu Stanisława Kani, nowego pierwszego sekretarza KC PZPR, że polityka wyznaniowa zmierzająca do normalizacji stosunków Kościół - państwo będzie kontynuowana. Minister J. Kuberski poinformował też o przebiegu posiedzenia plenarnego KC PZPR, które odbyło się w nocy z 5 na 6 września. Obrady rozpoczęły się o godz. 23.00, a zwołał je Henryk Jabłoński, gdyż kilka godzin wcześniej (godz. 16.00) lekarze stwierdzili rozległy zawał serca i w konsekwencji beznadziejny stan zdrowia Edwarda Gierka. Biuro Polityczne KC PZPR rekomendowało natychmiastowy wybór nowego pierwszego sekretarza i przedstawiło kandydaturę Stanisława Kani, który został wybrany jednogłośnie. Obrady zakończono ok. godz. 1.00 dnia 6 września ${ }^{61}$.

W połowie października 1980 r. sekretarz Konferencji Episkopatu Polski informował biskupów o obstrukcyjnej postawie Aleksandra Merkera, wicedyrektora Urzędu do Spraw Wyznań, w kontaktach z przedstawicielami Kościoła, który utrudnia merytoryczne załatwianie poszczególnych problemów. Od dyrektora, jak stwierdził biskup, „odbijają się" niemal wszystkie sprawy przesyłane z diecezji. Podobnie jest z Okólnikiem Urzędu do Spraw Wyznań z 2 października 1980 r., gdzie zawarty został zapis: „USW wyda w celu sporządzenia odpowiednich umów notarialnych, zaświadczenie o spełnieniu przez zakon ........ obowiązku wynikającego z rozporządzenia z 6.VIII.1949 r.”, co dyr. Merker interpretuje w ten sposób, że zaświadczenia takie winny być wydawane dla każdej sprawy oddzielnie ${ }^{62}$. Biskup Dąbrowski podkreślił, że nowy kierownik Urzędu do Spraw

${ }^{61}$ Sprawozdanie z rozmowy przeprowadzonej z min. J. Kuberskim. Warszawa 6.IX.1980 r. g. 12.30-13. Warszawa, 06-09-1980. AKEP, sygn. III 030. Biskup Dąbrowski w czasie rozmowy skomentował przekazane informacje, że władze powinny pozbywać się swoich kadr kierowniczych w sposób bardziej humanitarny. Tamże.

${ }^{62}$ Bp B. Dąbrowski. Pro memoria na 176. Konferencję Episkopatu Polski Warszawa, 15-16.X.1980 r. Warszawa, 13-10-1980. AKEP, sygn. III 013, s. 4-5. 
Wyznań min. Jerzy Kuberski działa sprawniej od swego poprzednika i jak się wydaje, ma szersze uprawnienia i posiada wizję normalizacji stosunków państwo - Kościół. Zdaje on sobie sprawę, że w końcu władze staną przed koniecznością uregulowania osobowości publiczno-prawnej Kościoła ${ }^{63}$.

W tym samym miesiącu, w imieniu Konferencji Episkopatu Polski, zostało wystosowane pismo do premiera Józefa Pińkowskiego, podpisane przez kard. Franciszka Macharskiego, wiceprzewodniczącego Konferencji Episkopatu Polski, i ks. Alojzego Orszulika, zastępcy sekretarza Konferencji Episkopatu, w którym stwierdzono, że istnienie w Polsce cenzury należy traktować jedynie jako sytuację wyjątkową i przejściową, związaną ze szczególnymi okolicznościami. Zaznaczono w piśmie, że wszyscy są zgodni, iż działanie cenzury wyrządzało narodowi i państwu ogromne szkody, co wielokrotnie podkreślali biskupi polscy. Konieczne jest, aby przygotowywana nowa ustawa dotycząca cenzury w radykalny sposób ograniczała zakres kompetencji tych organów, które muszą być poddane skutecznej, stałej kontroli. Organy cenzury nie mogą ograniczać wolności słowa i publikowania ani dostępu do środków społecznego przekazu i rozpowszechniania wytworów kultury. Zdaniem autorów pisma istnieje konieczność umieszczenia w nowej ustawie gwarancji dotyczących prawa obywateli do: pełnej informacji o wydarzeniach krajowych i międzynarodowych, krytyki negatywnych zjawisk życia społecznego, wolnego prezentowania systemów filozoficznych i religijnych, obiektywnej prezentacji różnych kierunków myśli społecznej i politycznej, pełnego poznania dziejów ojczystych i dziedzictwa kulturalnego, swobody badań naukowych i twórczości artystyczno-kulturalnej. Natomiast tryb działania organów cenzury powinien opierać się na przepisach Kodeksu postępowania administracyjnego ${ }^{64}$.

W omawianym okresie przedstawiciele władzy komunistycznej w Polsce prosili o spotkania bpa B. Dąbrowskiego w sprawach, które ich zdaniem, wymagały pilnego kontaktu, szczególnie w związku

\footnotetext{
${ }^{63}$ Tamże, s. 7.

${ }^{64}$ Kopia pisma. Kard. F. Macharski i ks. A. Orszulik do J. Pińkowskiego. Warszawa, 30-10-1980. AKEP, sygn. III 0305.
} 
z niepokojami społecznymi. Do takich rozmów doszło w końcu stycznia 1981 r., gdy sekretarz Konferencji Episkopatu Polski spotkał się z Kazimierzem Barcikowskim, sekretarzem KC PZPR i min. Jerzym Kuberskim, kierownikiem Urzędu do Spraw Wyznań. Przedstawiciele władz komunistycznych oświadczyli, że w kraju narasta fala strajków, gospodarka jest w fatalnym stanie, a kredyty bardzo szybko się kurczą. „Solidarność” nie przyjęła propozycji rządu, aby utworzyć Komisję Mieszaną i na jej forum przedyskutować problemy. Biskupa Dąbrowskiego wprost nie poproszono o interwencję Kościoła w Polsce, ale wydaje się, że była taka intencja władz, gdyż sytuację w kraju przedstawiono jako bardzo tragiczną ${ }^{65}$.

W końcu lipca 1981 r. o spotkanie z bpem B. Dąbrowskim poprosił też wicepremier Mieczysław Rakowski, który poinformował rozmówcę, że Polska weszła w nowy etap kryzysu - manifestacji ulicznych, podając konkretne przykłady. Zdaniem wicepremiera eskalacją protestów kierują opozycjoniści, podburzając członków „Solidarności”. W zaistniałej sytuacji nie można wykluczyć prowokacji. Jak stwierdził Rakowski, „zawiedzeni towarzysze atakują Kanię i Jaruzelskiego". Zdaniem wicepremiera działają tu dwie przeciwstawne grupy - usunięci partyjni i opozycjoniści jednoczą się przeciw rządowi i jest wyraźne dążenie do obalenia władzy. W tym aspekcie wicepremier postawił pytanie: „Co robić?”66. Odpowiadając, sam stwierdził, że należy poprawić stan gospodarki i opanować niepokoje. Każda iskra, jego zdaniem, może spowodować wybuch i całkowitą destabilizację kraju. Biskup Dąbrowski zwrócił uwagę rozmówcy, że władze wychodzą z błędnych założeń. Strach i nerwy są zawsze złymi doradcami i należy wykazać się spokojem i rozwagą. Zdaniem

${ }^{65}$ Bp B. Dąbrowski. Rozmowa Sekretarza Episkopatu Biskupa B. Dąbrowskiego z Sekretarzem K. Barcikowskim i min. J. Kuberskim Warszawa 28 stycznia 1980 r. Warszawa 28-01-1981. AKEP, sygn. III 013. W tytule relacji z rozmowy pomylono rok. Zamiast 1981 r. umieszczono $1980 \mathrm{r}$.

${ }^{66}$ Bp B. Dąbrowski. Sprawozdanie z przeprowadzonej rozmowy z wiceministrem M. Rakowskim Warszawa, Urząd Rady Ministrów 31.VII.81 g. 17-18. Warszawa 01-081981. AKEP, sygn. III 013. W tytule sprawozdania błędnie podano, że M. Rakowski w tym czasie był wiceministrem, tymczasem sprawował funkcję wicepremiera. 
sekretarza Konferencji Episkopatu optyka władzy jest zmanipulowana przez dochodzące do niej informacje o stanie rzeczy. Przede wszystkim należy poczynić wysiłki, aby poprawić sytuację ekonomiczną obywateli. Wicepremier Rakowski przywołał w rozmowie pomysł powołania Komitetu Ocalenia Narodowego. Biskup Dąbrowski zauważył, że Komitet nie może powstać przy Froncie Jedności Narodu i z udziałem partii i rządu, gdyż taka formuła nie zda egzaminu ${ }^{67}$.

W czasie tego rodzaju spotkań, wydaje się, że władze komunistyczne PRL starały się wywierać presje na przedstawicieli Konferencji Episkopatu Polski. Wprost nie formułowano oczekiwań, ale przedstawiano tragizm sytuacji społeczno-ekonomicznej w Polsce i stawiano retoryczne pytania: „Co robić? Jak dalej potoczą się wydarzenia?”.

W dniu 4 listopada 1981 r. doszło do trójstronnego spotkania Wojciecha Jaruzelskiego, prezesa Rady Ministrów, abpa Józefa Glempa, przewodniczącego Konferencji Episkopatu i prymasa Polski, oraz Lecha Wałęsy, przewodniczącego Komisji Krajowej NSZZ „Solidarność". Dokonano wstępnej wymiany poglądów na temat konieczności podjęcia działań w celu przeprowadzenia koniecznych reform zapewniających wpływ obywateli na życie kraju. Premier Jaruzelski zadeklarował, że rząd zdecydowany jest przestrzegać porozumień społecznych i rozwiązywać konflikty wyłącznie środkami politycznymi. Lech Wałęsa oświadczył, że NSZZ „Solidarność” opiera swą działalność na porozumieniach społecznych, co jest równoznaczne $\mathrm{z}$ uznaniem porządku konstytucyjnego, a spokój publiczny w kraju, wymaga, by istniejące problemy były rozwiązywane zgodnie z dążeniem społeczeństwa. Natomiast abp Glemp podkreślił znaczenie właściwych postaw moralnych w funkcjonowaniu struktur społecznych i państwowych ${ }^{68}$. Następnie gen. Jaruzelski przedstawił ideę powołania Rady Porozumienia Narodowego, w której powinni się znaleźć przedstawiciele głównych sił społecznych. Lech Wałęsa zadeklarował, że powołanie Rady Porozumienia Narodowego będzie przedmiotem dyskusji we

\footnotetext{
${ }^{67}$ Tamże, s. 7.

${ }^{68}$ Sprawozdanie ze spotkania premiera W. Jaruzelskiego, abpa J. Glempa i L. Wałęsy w dniu 4.XI.1981 r. (bez daty i podpisu). AKEP, sygn. III 013.
} 
władzach „Solidarności”, a ewentualne uczestnictwo w tym gremium strony społecznej będzie uzależnione od roli jaką będzie pełnić Rada i głębokości zaproponowanych reform życia publicznego, uwzględniając porozumienia sierpniowe. Jednocześnie Lech Wałęsa przedstawił koncepcję powołania Społecznej Rady Gospodarki Narodowej, która miałaby być społecznym organem niezależnym od rządu i wyposażona w skuteczne instrumenty działania na rzecz przezwyciężenia kryzysu gospodarczego i wprowadzenia reform ekonomicznych. Na zakończenie spotkania poruszono kwestię dostępu „Solidarności” i Kościoła do środków masowego przekazu, a także wymieniono poglądy na temat społecznej kontroli organów władzy. Premier stwierdził, że rząd jest zainteresowany, aby jego działania były poddane społecznej kontroli. Wyrażono postulat wobec gen. Jaruzelskiego, aby zmierzał on do rekonstrukcji rządu w oparciu o szeroką reprezentację społeczną, aby w ten sposób osiągnął wysokie zaufanie społeczne ${ }^{69}$.

\section{Podsumowanie i wnioski}

W omawianym okresie władze PRL zmieniły swoje podejście do sposobu unormowania relacji z Kościołem w Polsce w stosunku do działań podejmowanych poprzednio w latach siedemdziesiątych ubiegłego wieku. Wówczas dążono do porozumienia dyplomatycznego ze Stolicą Apostolską z wykluczeniem biskupów polskich. To się nie udało, gdyż przedstawiciele Stolicy Apostolskiej stanowczo stwierdzili, że w ramach prowadzonych negocjacji z poszczególnymi państwami zawsze uwzględniają stanowisko odpowiednich konferencji biskupów i tak stało się w tym przypadku. Na zmianę postawy negocjacyjnej władz polskich niewątpliwie miały też wpływ wydarzenia społeczno-ekonomiczne w Polsce. W lecie 1980 r. dochodziło do niepokojów społecznych i strajków, których podłożem było ciągłe ograniczanie przez władze komunistyczne PRL praw obywatelskich i wolności w różnych sferach życia społecznego. Został powołany do istnienia Niezależny Samorządny Związek Zawodowy „Solidarność”, a związkowcy, w przedstawionych władzy postulatach, żądali respektowania

\footnotetext{
${ }^{69}$ Tamże.
} 
wolności obywatelskich, możliwości zrzeszania się w wolnych związkach zawodowych i godziwego wynagrodzenia za pracę. W zaistniałej sytuacji społeczno-ekonomicznej władze komunistyczne nie mogły sobie pozwolić na dalszy, otwarty konflikt z Kościołem katolickim w Polsce, co skłoniło je do prowadzenia dwustronnych rozmów, głównie na forum Komisji Wspólnej przedstawicieli rządu i Episkopatu.

Po podpisaniu porozumień sierpniowych, nastąpiły zmiany personalne w kierownictwie PZPR i rządzie. Na pierwszego sekretarza KC PZPR został wybrany Stanisław Kania, a na premiera powołano Józefa Pińkowskiego i jednocześnie dokonano wymiany kadr na niższych szczeblach. Wówczas zmieniło się podejście władz PRL do prowadzenia rozmów z Episkopatem Polski. We wrześniu tego roku, po ponad dziesięciu latach, reaktywowano Komisję Wspólną przedstawicieli rządu i Episkopatu. Ogólne zasady pracy Komisji strony ustaliły na pierwszym posiedzeniu tego gremium w drugiej połowie września 1980 r. Uszczegółowiono je podczas rozmowy przeprowadzonej przez bpa Bronisława Dąbrowskiego, sekretarza Konferencji Episkopatu Polski z min. Jerzym Kuberskim, kierownikiem Urzędu do Spraw Wyznań w październiku. Na forum Komisji Wspólnej powołano pięć następujących zespołów roboczych do omówienia poszczególnych kwestii będących w zainteresowaniu stron ${ }^{70}$ : do Spraw Seminariów Duchownych, do Spraw Walki z Alkoholizmem i Wychowania w Trzeźwości, do Spraw Legislacyjnych, do Spraw Wydawnictw i Czasopism, do Spraw Wychowania oraz dodatkowo jeden zespół nieformalny do Spraw Działalności Zakonów i Instytutów ${ }^{71}$.

Strona rządowa zgodziła się uznać Papieskie Fakultety Teologiczne w: Krakowie, Wrocławiu, Poznaniu i Warszawie, z możliwością nabywania przez te podmioty majątku, ubezpieczenia społecznego pracowników, uznania stopni i tytułów naukowych oraz zobowiązała

\footnotetext{
${ }^{70}$ Sekretariat Konferencji Episkopatu Polski. Komisja Wspólna (działalność od 24.IX.1980 r.-27.VIII.1981 r.). Warszawa, 18-09-1981. AKEP, sygn. III 0305.

${ }^{71}$ Zob. Sekretariat Konferencji Episkopatu Polski. Załącznik. Komisja Wspólna (działalność od 24.IX.1980 r.-27.VIII.1981 r.). Warszawa, 18-09-1981. Skład osobowy Komisji Wspólnej i zespołów roboczych. AKEP, sygn. III 0305.
} 
się do niezwłocznego wydania odpowiednich aktów prawnych w tych sprawach $^{72}$. W wyniku porozumień zawartych na forum Komisji Wspólnej, uregulowano prowadzenie duszpasterstwa w szpitalach, sanatoriach, domach opieki, zakładach poprawczych i penitencjarnych, a także objęto ubezpieczeniem społecznym osoby pracujące w instytucjach kościelnych. Władze państwowe wyraziły zgodę na budowę wyższych seminariów duchownych w Koszalinie, Szczecinie i Gnieźnie, rozbudowę „Księżówki” w Zakopanem oraz uruchomienie przez Konferencję Episkopatu Polski wydawnictwa i drukarni ${ }^{73}$.

W omawianym okresie, główną płaszczyzną prowadzenia rozmów i negocjacji była Komisja Wspólna przedstawicieli rządu i Episkopatu Polski, to jednocześnie do kontaktów dochodziło także między bpem Bronisławem Dąbrowskim, sekretarzem Konferencji Episkopatu Polski, a najpierw Stanisławem Kanią, a później Kazimierzem Barcikowskim, sekretarzami KC PZPR i jednocześnie upoważnionymi do prowadzenia rozmów z Kościołem w imieniu PZPR. Odbywały się także robocze spotkania i wymiana korespondencji z innymi przedstawicielami władz. W tym miejscu należy odnotować rozmowy trójstronne, do jakich doszło w dniu 4 listopada 1981 r. między Wojciechem Jaruzelskim, wówczas prezesem Rady Ministrów, abpem Józefem Glempem, przewodniczącym Konferencji Episkopatu i prymasem Polski, oraz Lechem Wałęsą, przewodniczącym Komisji Krajowej NSZZ „Solidarność”.

W latach 1980-1981 władze PRL zgodziły się na załatwienie niektórych spraw, chociaż nie osiągnięto kompleksowego porozumienia. Biskupi polscy byli świadomi, że wówczas władze komunistyczne nie były gotowe do całościowego uregulowania relacji między państwem a Kościołem, w tym przede wszystkim statusu prawnego i wolnego funkcjonowania Kościoła w Polsce, głównie ze względu na uzależnienie od władz sowieckich, nacisków ze strony frakcji w PZPR zmierzającej do zaostrzenia kursu wobec Kościoła.

\footnotetext{
${ }^{72}$ Sekretariat Konferencji Episkopatu Polski. Komisja Wspólna (działalność od 24.IX.1980 r.-27.VIII.1981 r.). Warszawa, 18-09-1981. AKEP, sygn. III 0305, s. 5.

${ }^{73}$ Zob. tamże, s. 8, 13-14, 16, 20.
} 


\section{Zakończenie}

W 1979 r. członkowie Rady Stałej Konferencji Episkopatu Polski skierowali list do papieża Jana Pawła II, w którym dokonali analizy stosunków Kościół - państwo. Postulowali kontynuowanie rozmów na temat normalizacji stosunków między Kościołem i państwem w Polsce. Stwierdzili, że należy szukać nowych inicjatyw, aby wyjść z zastoju, jaki daje się zaobserwować we wzajemnych relacjach. Podkreślili, że władze PRL dotychczasowe kontakty z Kościołem traktowały propagandowo i taktycznie, niejednokrotnie wykorzystując je instrumentalnie do aktualnych celów politycznych ${ }^{74}$.

W początku lat osiemdziesiątych nastąpiły zmiany personalne we władzach PZPR i rządu, a nowy Prezes Rady Ministrów zadeklarował chęć normalizacji stosunków państwo - Kościół i reaktywowania Komisji Wspólnej przedstawicieli rządu i Episkopatu. Biskupi polscy i tym razem odpowiedzieli pozytywnie na tę deklarację władz. Głównym forum rozmów dwustronnych stała się Komisja Wspólna przedstawicieli Rządu PRL i Episkopatu Polski. W latach 1980-1981 odbyło się jedenaście posiedzeń tej Komisji ${ }^{75}$ i chociaż nie osiągnięto całościowego porozumienia, to jednak można stwierdzić, że w tym czasie władzom komunistycznym PRL zależało na poprawie stosunków państwa z Kościołem w Polsce. Rządzący liczyli przede wszystkim na pomoc Kościoła w uspokojeniu nastrojów społecznych i normalizacji sytuacji, po niepokojach i strajkach, jakie wówczas miały miejsce.

W trakcie prowadzonych rozmów biskupi polscy ciągle podkreślali, że pełna i całościowa normalizacja stosunków między władzami PRL a Kościołem jest możliwa po uznaniu przez państwo osobowości publiczno-prawnej Kościoła w Polsce i jego instytucji, a także po prawnym i faktycznym zapewnieniu wolności sprawowania kultu i prowadzenia działalności duszpasterskiej. Przedstawiciele

\footnotetext{
${ }^{74}$ List. Członkowie Rady Stałej Konferencji Episkopatu Polski do Jana Pawła II. Warszawa, 11-10-1979. AKEP, sygn. II 0200.

${ }^{75}$ Sekretariat Konferencji Episkopatu Polski. Zestaw posiedzeń Komisji Wspólnej od 1980 roku (bez daty). AKEP, sygn. III 03059, s. 5.
} 
Konferencji Episkopatu Polski niezmiennie stali na stanowisku, że do uspokojenia nastrojów społecznych niezbędne jest respektowanie w Polsce praw i wolności obywatelskich, zaprzestanie wszelkiej dyskryminacji, w tym ze względu na wyznawaną religię i zaniechanie indoktrynowania społeczeństwa ideologią marksistowską.

\section{Relations of the Conference of the Episcopate of Poland with the authorities of the Polish People Republic in the years 1980-1981}

After the Second World War communists took over the power in Poland. The main purpose of the ruling party was introducing the principles of Marxist philosophy. In the center of ideological fight was the Roman Catholic Church perceived as serious obstacle or even threat in achieving their goals.

In the years 1980-1981, the Polish authorities again declared their will to normalize relations and to reactivate the Joint Commission of the Government and the Episcopate. The communists as the rulers counted on the help of the Church in calming social moods and normalizing the situation after the unrest and strikes that took place at that time. The talks however did not bring any significant effects. Only a few small matters were settled.

SŁowa Kluczowe: Konferencja Episkopatu Polski; Polska Rzeczypospolita Ludowa; relacje; władze komunistyczne

Keywords: the Conference of the Episcopate of Poland; Polish People Republic; relations; communist authorities

\section{Nota O AUTORzE}

Ks. DR hab. MARek StęPIEŃ, PRof. UCZelNi - dr hab. nauk prawnych w zakresie prawa kanonicznego, profesor uczelni w Katedrze Ustroju Kościoła Powszechnego i Kanonicznych Form życia Konsekrowanego, kierownik Zakładu Praw i Obowiązków Wiernych. 